には鮮鋭度のよい写真でなければならず，500 $\mathrm{mA}$ 程度 の大電流で数 $\mathrm{ms}$ の極短時間撮影のできる装置で， $1 \times$ $1 \mathrm{~mm}$ 程度の小焦点管球を使う．3）腹部は腸内ガス, 腹 水の貯溜や滲出淮状態をみるには立位がよく, 巨大結腸 症では腸内ガスを肛門部へ集めるために倒立位が要求さ れ, 傾斜, 倒立固定撮影台を使う。4)股関節は計測部 位の再現性之性腺防護板の位置つれ防止のために確夷な 固定が要求される。また，性腺の被曝線量を少なくする ために $0.5 \mathrm{mmPb}$ 以上の鉛ゴムを使い, 高感度フィルム と高感度増感紙を組み合わせている，5）沓柱と四肢は 左右対称性が要求され，腹部や股関節之共に体側圧迫固 定具と固定帯を使う. 以上, 診断の要求に即した写真を とるために，当病院で行なわれているポジショニング, 固定法, 防護法などを報告する。

\section{シンポジゥム】「高エネルギー照射装置 による治療計画のあり方」}

座長 松本 健 （国立がんセンター）

木島常実（大阪府立病院）

上田 修（国立名古屋病院）

野原弘基 (京都大学病院)

石原 浩 （島津製作所）

雄川恭行（大阪大学病院）

會西 誠（石川県放射線治療技術研究

$$
\text { グループ) }
$$

齢龟一郎（放射線医学総合研究所）

\section{1. 身体計測と病巣位置の確認}

\section{大阪府立病院放射線治療科}

○木島常害 村野喜彦 浜本 哲

身体計測と病巣位置の確認は, 治療計画の第一歩であ

り，照射範囲・照射法の決定に際し必須の要件である。

我々の施設では, 治潦装置と同じ幾何学的条件を満し た透視・撮影を目的としたX線装置 (simulator) と, 回 転横断撮影装置があり，所期の目的のために駆使してい る.

Simulator には，管球前面に Acryle 製 scale と揩動す る鉛線（補助絞り）があり， scale は，上下に移動可能 で, 管球焦点からの距離を任意に選択することにより, 皮膚面は勿諭, 病策面上での大きさが分り, また, 補助 校りを, 照射野の大きさに開くと, 治療部位と周辺藏器 との位置関係が同時に分る.

Simulator と回転横断撮影装置の管球焦点を, 同一円 弧上に位置する様装置を配置しているので, 撮影用茛
台の方向を変えるだけで, simulator で定められた位置 の回転横断撮影ができる.

回転横断写真で, 病巣の体内位置や患部を含む人体の大 きさ, 形, 他臓器との位置関係で判然とするが, 我々は, 回転横断写真の画質の向上を計るため, 先に発表した風 車絞りを開発した。

人体横断図作成には, 回転横断写真の拡大率が1. 33倍 のため, 実物大汇縮少の必要が尚り, 1 目盛 $1.33 \mathrm{~cm}$ に 目盛った Acryl 製の scale 板を, 写真上に貼付し, 写真 加ら知る各点の位置を，1 $\mathrm{cm}$ 目盛の所定の横断図用紙の 上に記入し，各影像を描写する。

頭頸部の写真は, 拻大率1.20倍の装置で撮影するため, 1. 20 分の 1 亿縮少する.

子宮頸癌では, リンパ管造影, 注腸, 膀胱造影, 膀胱 癌では, 膀胱造影, 注腸等を同時に行なって, 周辺の健 康な臟器の位置関係を正確に知るととにより, 治療計画 に必要な資料を提供し得る横断図作成に，心が付てい る.

\section{2. 放射線治療における回転横断撮影の応用とその意 義}

$$
\begin{array}{r}
\text { 国立名古屋病院 } O \text { 上田 修 加藤 訓 } \\
\text { 田中 稔 松田忠義 }
\end{array}
$$

〔目的】放射線治療の計画と実施に回転横断撮影をどの 様に応用しているかを，固定照射法，原体照射法，打抜 照射法, 電子線照射法のそれぞれの場合について説明し その意義を述べる:

〔方法]装置は東芝製臥位回転横断撮影装置及びLMR13ライナックである．私共の長年にわたる回転横断撮影 の改良に関する研究で横断写真の画質は格段に改善され た，回転横断撮影を放射線治療に虑用ずる場合，その撮 影にいくつかの工夫が必要である，その状況を先つ説明

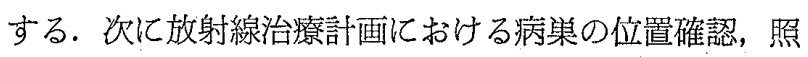
射方法, 線量計算に回転横断撮影をどの様に利用するか を実際の症例を例にして説明する.

1. 固定照射法：肺癌に おける病坚位置が胸壁の近く にある場合に横断写真をむとにすると斜対向二開照射が 適しており, その写真加らX線束の傾斜角度, 楔フィル ターなどの選定が正確容易にできる.

2. 原体照射法：可変絞り照射装置を使用する場合， 横断写真の所見をるとにすると病巣の位䈯, 病宩の形状 と大きさ等が正確に確認出来る.

3. 打拔照射法 : 上頢癌の眼球, 喉頭癌の頸解等の打 拔さ照射の場合，回転横断写真をむとにすると打拔部位 の選定，及びその大きさ，病监と打拔部位との位置関係 